\title{
PENGETAHUAN MASYARAKAT TERHADAP KESIAPSIAGAAN MENGHADAPI BENCANA TANAH LONGSOR
}

\author{
Sri Sulastri \\ Akper Kesdam 1/Bukit Barisan Padang \\ e-mail: srisulastri1329@gmail.com
}

\begin{abstract}
Abstrak
Negara Indonesia yaitu negara rawan bencana dikarenakan posisi geografis yang terletak di pertemuan tiga lempeng tektonik. Kota Padang adalah salah satu wilayah yang rawan akan bencana sehingga hal tersebut dapat mengganggu kehidupan masyarakat serta mengancam keselamatan penduduk. Penelitian ini bertujuan untuk mengetahui pengetahuan masyarakat terkait kesiapsiagaan dalam menghadapi bencana Tanah Longsor di Wilayah Kerja Puskesmas Bungus Teluk Kabung.Teknik Pengambilan sampel dalam penelitian ini menggunakan teknik total sampling yaitu 30 orang yang datang ke puskesmas Bungus Teluk Kabung diambil menjadi sampel. Berdasarkan hasil dari penelitian ini didapatkan yaitu dari pengetahuan masyarakat terhadap kesiapsiagaan menghadapi bencana Tanah Longsor yaitu dari 30 orang 24 orang $(80 \%)$ memiliki pengetahuan kurang baik dan 6 orang (20\%) memiliki pengetahuan baik. Oleh karena itu diperlukan pemantauan, sosialisasi, seminar, kerjasama yang melibatkan masyarakat dan perusahaanperusahaan swasta maupun instansi agar bersama-sama turut andil dalam meningkatkan kesadaran dalam berperi laku sehingga sikap peduli dan siaga dalam menghadapi bencana tanah longsor akan semakin meningkat dan terjaga.
\end{abstract}

Kata kunci: Pengetahuan kebencanaan, Sikap, Kesiapsiagaan, Bencana Tanah Longsor.

\begin{abstract}
Indonesia is one of the countries that experienced disasters related to Indonesian territory. Indonesia has more than 128 active volcanoes and around 150 rivers that cross densely populated areas. The earthquake and tsunami that occurred in Aceh in 2009 which had a major impact in several regions in Indonesia, one of which was Padang City. This can save people's lives. Loose research in the working area of the Bungus Bay Kabung Health Center. Sampling using total sampling techniques, as many as 30 people who came to the Bungus Teluk Kabung health center. Based on the results of research obtained by the public's knowledge of preparedness to face a landslide disaster that is from 30 people 24 people (80\%) have poor knowledge and 6 people (20\%) have good knowledge. Therefore renewal, socialization, seminars, cooperation needed by the community and private companies are needed and cooperation is needed to jointly contribute to raising awareness in the fight in order to raise awareness and awareness in an emergency situation where landslides will increase and increase.
\end{abstract}

Keywords: Disaster knowledge, Attitude, Preparedness, Landslide Disaster. 


\section{PENDAHULUAN}

Keselamatan segenap bangsa Indonesia erat kaitannya dengan kejadian bencana yang terjadi di Indonesia yang merupakan salah satu ancaman nirmiliter yang harus diperhatikan dan ditangani dengan tepat. Salah satu faktor penting dalam penanggulangan bencana adalah kesiapsiagaan masyarakat.

Bencana alam merupakan salah satu ancaman nirmiliter yang berakibat kepada keselamatan umum yang dapat mengganggu pertahanan Negara. Selain menjadi salah satu ancaman berskala nasional, bencana alam juga menjadi tantangan berdimensi lokal.

Definisi kesiapsiagaan di masyarakat berbeda antara satu masyarakat dengan yang lainnya. Kesiapsiagaan berarti merencanakan tindakan untuk merespons ketika terjadi bencana.

Kesiapsiagaan juga dapat didefinisikan sebagai keadaan siap siaga dalam menghadapi krisis, bencana atau keadaan darurat lainnya. Kesiapsiagaan bertujuan untuk meminimalkan efek samping bahaya melalui tindakan pencegahan yang efektif, tepat waktu, memadai, efesiensi untuk tindakan tanggap darurat dan bantuan saat bencana.

Pendapat ini didukung adanya Pasal 1 Undangundang No.24 Tahun 2007 tentang Penanggulanga Bencana yang menerangka bahwa kesiapsiagaan adalah serangkaian kegiatan yang dilakukan untuk mengantisipasi bencana melalui pengorganisasian serta melalui langkah yang tepat guna dan berdaya guna.

Mengingat tingginya risiko bencana longsor dan rendahnya kapasitas masyarakat dalam menghadapi bencana di wilayah Kerja Puskesmas Bungus, maka peneliti berpendapat perlu dilakukan penelitian untuk mengukur tingkat pengetahuan kesiapsiagaan masyarakat dalam menghadapi bencana longsor.

\section{METODE}

Penelitian ini adalah penelitian kuantitatif, sampel diambil secara Random Sampling yaitu sampel sebanyak 30 Orang masyarakat yang hadir di puskesmas Bungus Teluk Kabung. Data didapatkan dengan cara pengisian kuesioner yang telah disiapkan tekait Pengetahuan masyarakat terkait kesiapsiagaan menghadapi bencana tanah longsor.

\section{HASIL}

\section{Analisis Univariat}

Hasil penelitian menunjukan Pengetahuan masyarakat yang dapat dilihat pada tabel 1 .

Tabel 1. Distribusi Frekuensi Pengetahuan masyarakat terhadap kesiapsiagan menghadapi bencana tanah longsor

\begin{tabular}{|l|c|c|}
\hline Pengetahuan & Frekuensi & \% \\
\hline Baik & 24 & $80 \%$ \\
\cline { 1 - 2 } Kurang Baik & 6 & $20 \%$ \\
\cline { 1 - 2 } Jumlah & $\underline{\mathbf{3 0}}$ & $\mathbf{1 0 0}$ \\
\cline { 1 - 2 } & &
\end{tabular}


Berdasarkan tabel 1 terlihat bahwa sebanyak 80 $\%$ responden memiliki pengetahuan kurang baik.

\section{PEMBAHASAN}

Mengacu pada Tabel 1, dapat disimpulkan pengetahuan kesiapsiagaan menghadapi bencana tanah longsor bagi masyarakat secara individu/perorangan memiliki kriteria kurang baik dan ini dibuktikan dengan nilai kurang baik yang mencapai $80 \%$ dari 24 responden dan 6 responden yang memiliki pegetahuan baik yaitu $20 \%$ dari 6 orang responden.

Pengetahuan terkait bencana adalah kemampuan dalam mengingat peristiwa atau rangkaian peristiwa yang mengancam dan mengganggu kehidupan dan penghidupan masyarakat yang disebabkan, baik oleh faktor alam dan/atau faktor non- alam maupun faktor manusia yang dapat mengakibatkan timbulnya korban jiwa manusia, kerusakan lingkungan, kerugian harta benda, dan dampak psikologis.

Hal senada juga dihasilkan oleh penelitian yang dilakukan oleh Khaira, (2010) dan Chotimah, (2015) bahwa sikap berpengaruh positif terhadap kesiapsiagaan.

Pengetahuan merupakan hasil "tahu" dan ini terjadi setelah orang melakukan penginderaan terhadap suatu objek tertentu. Sebagan besar pengetahuan manusia diperoleh melalui mata dan telinga.
Pengetahuan kebencanaan akan dibutuhkan masyarakat yang tinggal di daerah rawan bencana, karena berbagai informasi mengenai jenis bencana yang dapat mengancam mereka, gejala-gejala bencana, perkiraan daerah jangkauan bencana, prosedur penyelamatan diri, tempat yang disarankan untuk mengungsi, dan informasi lain yang mungkin dibutuhkan masyarakat pada sebelum, saat dan pasca bencana itu terjadi dapat meminimalkan risiko bencana.

\section{KESIMPULAN}

Berdasarkan hasil penelitian mengenai pengetahuan kebencanaan masyarakat terhadap kesiapsiagaan menghadapi bencana tanah longsor di wilayah kerja puskesmas bungus teluk kabung, maka penulis dapat menarik beberapa kesimpulan yaitu dari 30 responden sebagian besar masyarakat memiliki pengetahuan kebencanaan kurang baik yaitu sekitar $80 \%$ sedangkan sisanya memiliki pengetahuan baik yaitu seitar $20 \%$.

\section{SARAN}

Penelitian ini hanya meneliti satu variabel saja dan dengan responden yang relatif sedikit, sehingga hanya menggambarkan hasil penelitian yang sederhana, untuk itu, agar penelitian lanjutan menggunakan jumlah responden yang lebih besar dan dengan cakupan wilayah kerja yang lebih luas, serta dapat menambah variabel penelitian dengan menghubungkan pengetahuan dan sikap, perilaku responden. 


\section{DAFTAR PUSTAKA}

Azwar, S, (2011). Sikap Manusia. Teori dan Pengukurannya, Edisi 2, Yogyakarta: Pustaka Belajar.

Notoatmodjo, S. (2003). Konsep Perilaku dan Perilaku Kesehatan Dalam: Pendidikan dan Perilaku kesehatan. Jakarta: PT Rineka Cipta

Notoatmodjo, S. (2007). Domain Perilaku Dalam Promosi Kesehatan dan Ilmu Perilaku. Jakarta: PT Rineka Cipta

Khaira Nuswatul. (2010). "Pengaruh Faktor Pengetahuan, Sikap Dan Pendidikan Kepala Keluarga Terhadap Kesiapsiagaan Rumah Tangga Dalam Menghadapi Banjir Di Desa Pelita Sagoup Jaya Kecamatan Indra Makmu Kabupaten". Tesis, Universitas Sumatera Utara, Medan 2010. 
